\title{
Radiological Breast Evaluation Following Breast Reduction Surgery
}

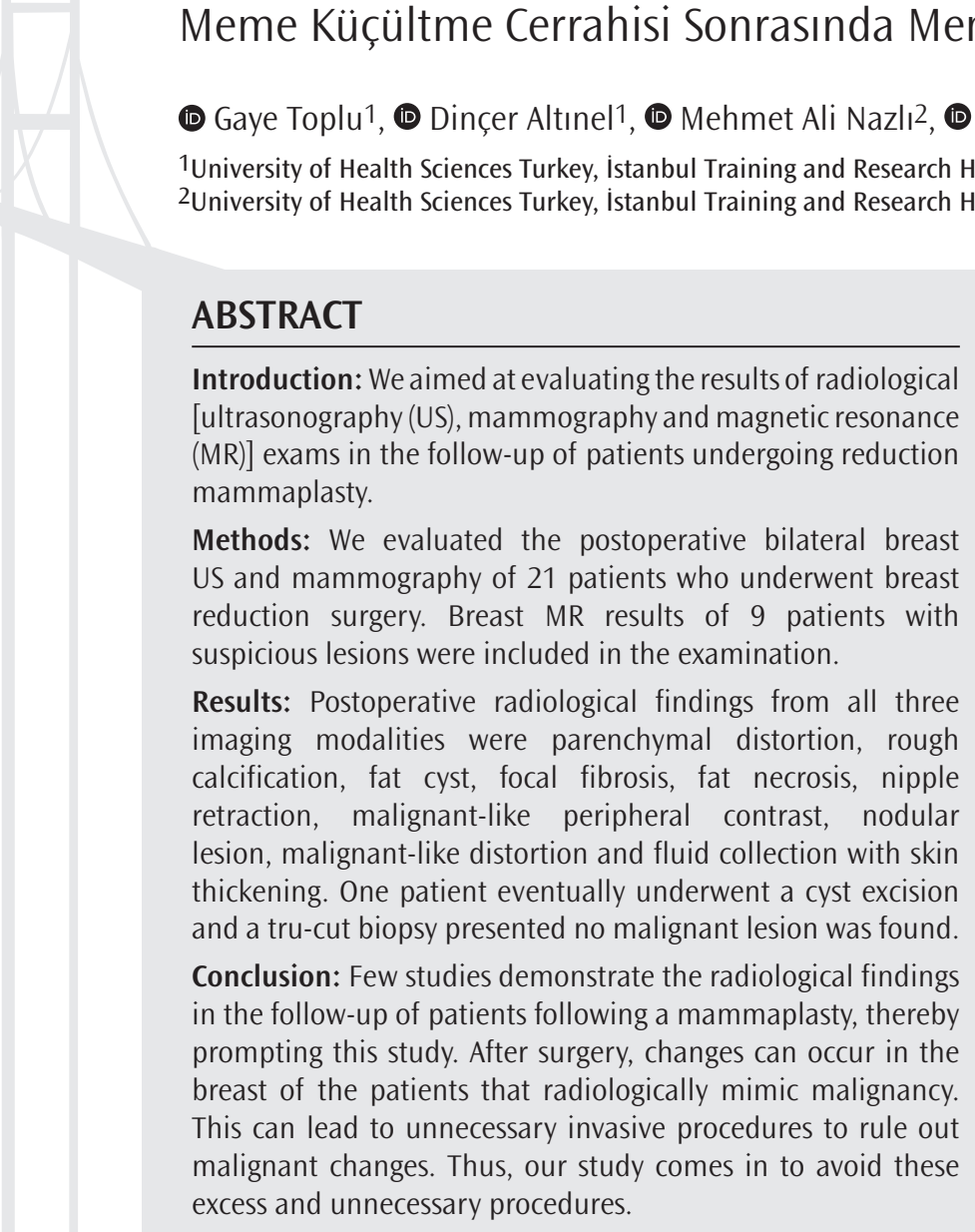

Keywords: Breast, breast cancer, mammaplasty

\section{öZ}

Amaç: Çalıșmamız redüksiyon mamoplasti ameliyatı geçiren hastaların takibinde radyolojik [ultrasonografi (US), mamografi ve manyetik rezonans (MR)] görüntüleme sonuçlarını değerlendirmeyi amaçlamaktadır.

Yöntemler: Ameliyat sonrası bilateral meme US'nin retrospektif değerlendirmesi ve meme küçültme ameliyatı geçiren 21 hastanın mamografisi yapıldı. Lezyon șüphesi olan 9 hastanın meme MR sonuçları muayeneye dahil edildi.

Bulgular: Parankimal distorsiyon, kaba kalsifikasyon, yağ kisti, fokal fibrozis, yağ nekrozu, meme bașı retraksiyonu, malign benzeri periferik kontrast, nodüler lezyon, malign benzeri distorsiyon ve deri kalınlașması ile sıvı toplanması üç görüntüleme yöntemini de içeren postoperatif radyolojik bulgulardı. Sonunda 1 hastaya kist eksizyonu ve tru-cut biyopsi yapıldı. Malign lezyon bulunmadı.

Sonuç: Meme küçültme ameliyatı sonrası hastaların takibinde saptanan radyolojik bulguları ve önemini gösteren az sayıda çalışma vardır. Ameliyat sonrasında hastaların meme dokularında radyolojik olarak maligniteyi taklit eden değişiklikler meydana gelebilir. Bu, kötü huylu değişiklikleri ekarte etmek için gereksiz invaziv prosedürlere yol açabilir. Cerrahların, radyologların ve onkologların bu konuda daha dikkatli olmaları gerekir.

Anahtar Kelimeler: Meme, meme kanseri, mammoplasti

\section{Introduction}

Breast-reduction surgery is among the most applied plastic surgeries in the world (1). Such patients are subjected to some changes in their breast that mimic malignancy-related findings in radiologic examinations, thereby prompting invasive or surgical procedures. Mammography in itself is usually not sufficient in the diagnosis, as well as ultrasound. However, magnetic resonance imaging (MRI) are usually requested for confirmation and occasionally lesions should be confirmed histopathologically with a biopsy $(2,3)$. Fat necrosis in breast can occur as a result of previous breast surgery (lumpectomy, reduction, augmentation), radiotherapy, anticoagulant therapy, trauma, Weber-Christian disease, granulomatous angiopanniculitis and polyarteritis nodosa (4-6). Fat necrosis in breast can sometimes be difficult to distinguish from a malignant lesion.

Breast fat necrosis is a common benign condition that can cause a wide variety of mammographic findings such as tissue lumps, calcifications, fatty cysts and localized skin thickening (7). There are various clinical and 
imaging features where fat necrosis is sometimes not easy to distinguish from malignancy and can even be asymptomatic (8). In addition, the doctor can sometimes detect pathological condition by mammography only $(9,10)$. To prevent biopsy, the mammographic spectrum of fat necrosis appearances must be recognized.

There are only limited number of studies in the literature that evaluate the clinical and radiological findings in long-term patient follow-up after breast reduction surgery. Therefore, we aimed to emphasizing the importance of radiological imaging in the long-term follow-up of patients who have undergone breast reduction surgery.

\section{Methods}

We examined the preoperative and postoperative findings (breast examinations and radiological imaging) in 21 patient files who underwent mammaplasty between January 2014 and January 2019. The study approval was obtained by University of Health Sciences Turkey, İstanbul Training and Research Hospital Ethical Committee (approval number: 2660, date: 08.01.2021). Informed consents were equally received from all the patients.

The superomedial pedicle technique was performed in 19 patients, inferior pedicle in 1 patient and free nipple technique in 1 patient. Prior to the surgery, mammographies and ultrasounds were performed for screening purposes and no pathological findings were found.

Detailed breast examination, bilateral breast ultrasonography (US) and mammography were requested for preoperative follow-up as well as for long-term annual follow-up of 21 patients in the study. Breast MR was requested in 9 patients with suspicious lesions. One patient eventually underwent a cyst excision and tru-cut biopsy, which revealed no malignant lesions.

In ultrasonographic examinations, both breasts and axilla were examined on different planes using a broadband linear probe of 10$14 \mathrm{MHz}$ (Toshiba Aplio 500, Minato, Tokyo, Japan). MRI examinations of cases with 1.5 Tesla MRI devices (GE Healthcare Signa HDi 1.5T, General Electric Medical Systems, Boston, MA, USA) were performed in the prone position with the breast coil. In all examinations, axial T1AG, fat-pressed axial and sagittal T2AG, diffusion-weighted and axial-plan fat-saturated T1-weighted dynamic contrast images were taken. Before the patient was taken into the MRI device, a catheter was inserted into the antecubital vein for the injection of the contrast agent.

\section{Statistical Analysis}

Descriptive analysis was performed using GraphPad Prism 7.0 software (GraphPad Software, Inc., La Jolla, CA, USA).

\section{Results}

The average age of the participants was $42.9 \pm 12$ years (range: $20-58$ ). Table 1, 2 reveal amongst others: The surgical technique, amount of breast resection, and the sternal notch-nipple areolar complex distance. Table 3 reveals clinical characteristics such as current diseases of participants, use of drugs and smoking. Histopathological examination of resected materials of all patients revealed no abnormalities. Scar revision surgery was performed in 2 patients (9.52\%). In another patient, a suspicious tender mass was found during physical examination two years after surgery. Tru-cut biopsy accompanied by ultrasonography was then performed and was compatible with fat necrosis. Fat cyst excision was performed in this patient and a malignancy was ruled (Table 4).

Postoperative radiological findings from all three imaging modalities included parenchymal distortion $(n=11 ; 52.3 \%)$, rough calcifications $(n=8 ; 38.0 \%)$, fat cyst $(n=7 ; 33.3 \%)$, focal fibrosis $(n=6 ; 28.5 \%)$, fat necrosis $(n=5 ; 23.8 \%)$, nipple retraction $(n=5 ; 23.8 \%)$, malignant-like peripheral contrast $(n=3 ; 14.2 \%)$, nodular lesions $(n=1 ; 4.7 \%)$, malignant-like distortion $(n=1 ; 4.7 \%)$ and fluid collection with skin thickening $(n=1$; 4.7\%) (Table 5, Figure 1-8). The most common MRI findings were parenchymal distortion and asymmetry, malignant-like contrast, nipple retraction, focal fibrosis, postoperative fluid collection and fat necrosis.

In mammography, fat necrosis was generally seen as coarse dystrophic calcifications. In some cases, calcifications were heterogeneous and

Table 1. Summary of patient information

\begin{tabular}{|l|l|l|}
\hline Mean age (years) & Mean \pm SD & Range \\
\hline Mean follow-up time (months) & $42.9 \pm 12$ & $20-58$ \\
\hline Left breast reduction $(\mathrm{mg})$ & $44 \pm 10$ & $12-60$ \\
\hline Right breast reduction $(\mathrm{mg})$ & $1190 \pm 410$ & $537-2100$ \\
\hline Left SN-NAC distance $(\mathrm{cm})$ & $1121 \pm 334$ & $630-1950$ \\
\hline Right SN-NAC distance $(\mathrm{cm})$ & $32 \pm 4$ & $27-40$ \\
\hline Planned SN-NAC distance $(\mathrm{cm})$ & $32 \pm 4$ & $27-40$ \\
\hline
\end{tabular}

SN-NAC: Sternal notch-nipple areolar complex, SD: Standard deviation

Table 2. Summary of surgical techniques

\begin{tabular}{|l|l|l|}
\hline & Frequency & Percentage \\
\hline Superomedial pedicle & 19 & $90.48 \%$ \\
\hline Inferior pedicle & 1 & $4.76 \%$ \\
\hline Free nipple graft & 1 & $4.76 \%$ \\
\hline Bilateral & 20 & $95.24 \%$ \\
\hline Unilateral & 1 & $4.76 \%$ \\
\hline
\end{tabular}

Table 3. Summary of patients' history

\begin{tabular}{|l|l|l|}
\hline & Number & Percentage \\
\hline Diabetes mellitus & 2 & $9.52 \%$ \\
\hline High blood pressure & 5 & $23.81 \%$ \\
\hline Drug use (progesterone) & 1 & $4.76 \%$ \\
\hline Insulin resistance & 1 & $4.76 \%$ \\
\hline Hypothyroidy & 1 & $4.76 \%$ \\
\hline Smoking & 4 & $19.05 \%$ \\
\hline Sleep apnea & 1 & $4.76 \%$
\end{tabular}

Table 4. Summary of surgery types

\begin{tabular}{|l|l|l|}
\hline & Frequency & Percentage \\
\hline Scar revision surgery & 2 & $9.52 \%$ \\
\hline Tru-cut biopsy & 1 & $4.76 \%$ \\
\hline Fat cyst excision & 1 & $4.76 \%$ \\
\hline
\end{tabular}



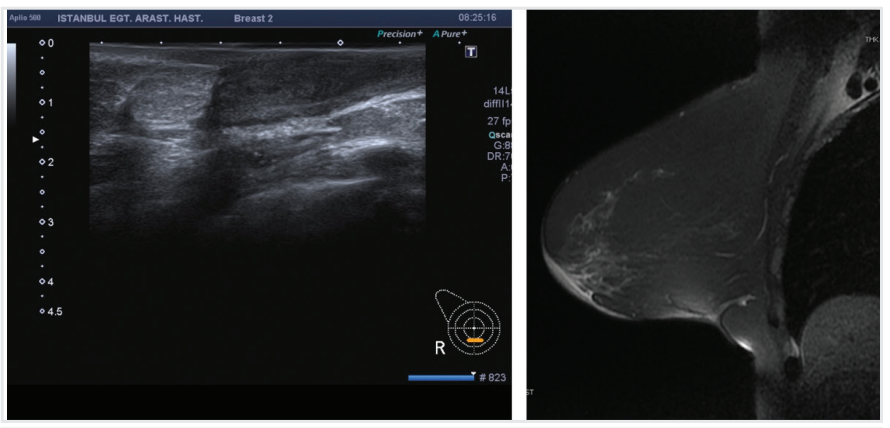

Figure 1. A 54-year-old patient, one year after breast reduction surgery, ultrasonography imaging (left) shows right breast periareolar skin thickening and skin edema, superficial fatty fluid collection. On magnetic resonance image (right; T2 fat-saturated sagittal image), there is skin edema, thickening in the periareolar area and inferior distortion in the incision line at the breast border in the periphery

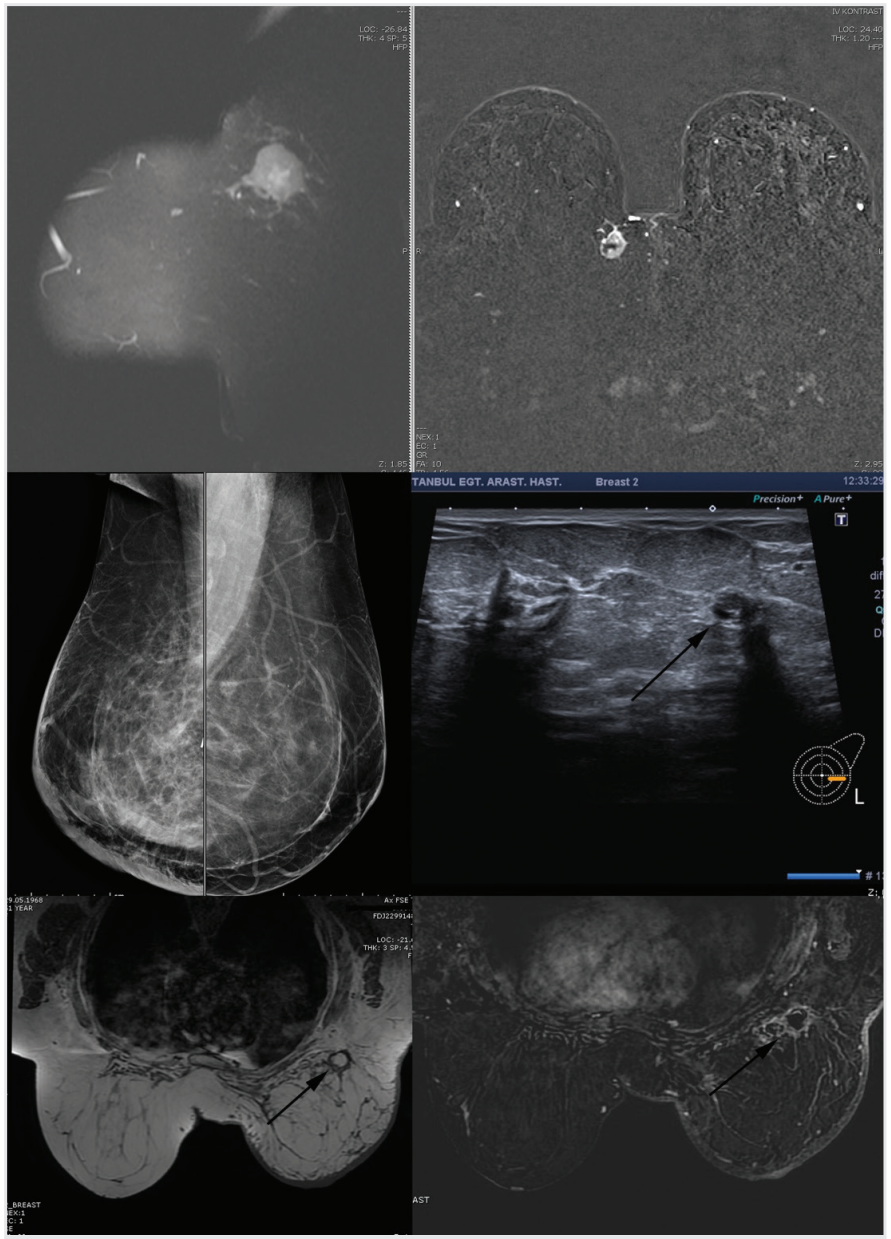

Figure 2. A 50-year-old patient with a right-sided skin-sparing mastectomy and left-sided reduction mammoplasty. Preoperative sagittal (upper left) and axial (upper right) T2, and dynamic contrasted magnetic resonance image (MRI) of the right breast showing high-grade malignant lesion with peripheral contrast uptake in the inner quadrant. Bilateral mammogram images of the patient ten months after surgery (middle left). Right breast showing radiotherapy-related skin thickness and general trabecular edema. Left breast image showing anterior contour lobulation and light distortion. Postoperative breast ultrasound images of the same patient. (middle right), millimetric fat cyst (black arrow) in the left breast outer quadrant are seen Right breast T1 weighted image and dynamic MRIs showing fat necrosis with peripheral fat necrosis and inflammation (lower left, lower right) biopsy was required for definitive diagnosis. In MRI, a fat necrosis could be perceived as a malignant-like distortion and mass-like appearance. MR contrast enhancement was seen in the periphery, especially in the early period following surgery and in cases of inflammation.
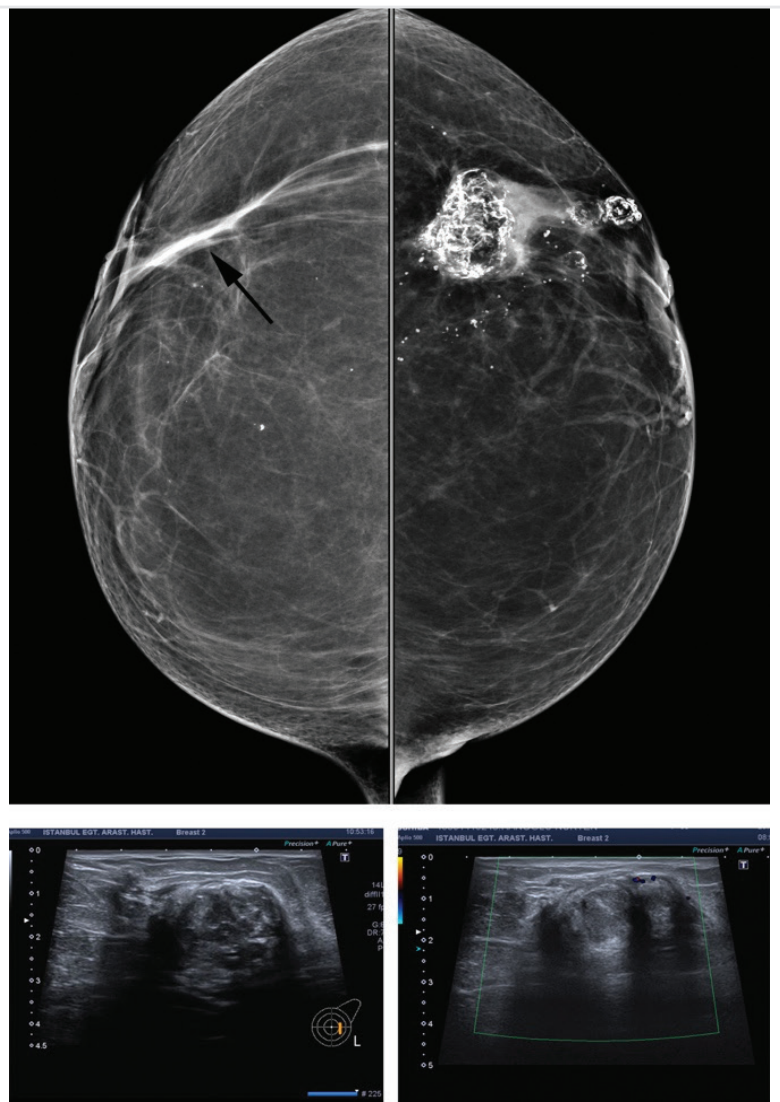

Figure 3. A 53-year-old woman postoperative $4^{\text {th }}$ year following breast reduction surgery. Bilateral mammography images revealing a band like thin distortion (black arrow) in the right breast left outer quadrant (upper left) and calcification and fat necrosis in the left breast (upper right). Left breast ultrasound images showing rough calcifications (lower right) and hyperechoic fatty cysts (lower left)
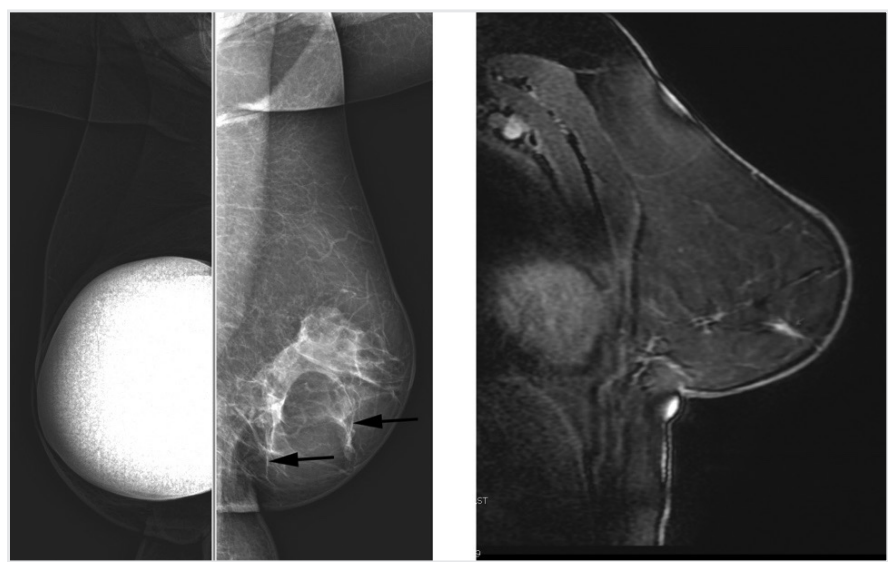

Figure 4. A 52-year-old patient three years following right breast implant reconstruction after a mastectomy, and a left reduction mammoplasty. Left breast reduction mammoplasty mammography image showing parenchymal distortion and fibrotic bands in the lower quadrant (left). Sagittal contrasted magnetic resonance image showing thin fibrotic band in the subareolar region of the lower quadrant (right) 

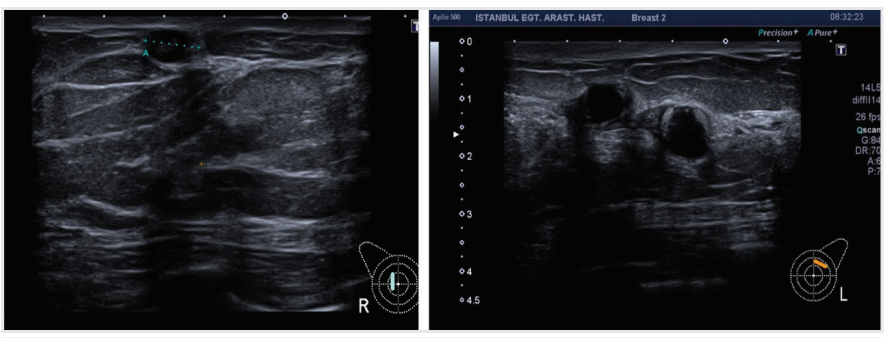

Figure 5. A 39-year-old patient's postoperative $4^{\text {th }}$ year radiological ultrasonography images following breast reduction. Right breast shows hypoechoic subcutaneous cysts in the outer peri areolar area (left). Left breast image reveals outer quadrant parenchymal superficial hypoechoic and hyperechoic cysts (right)

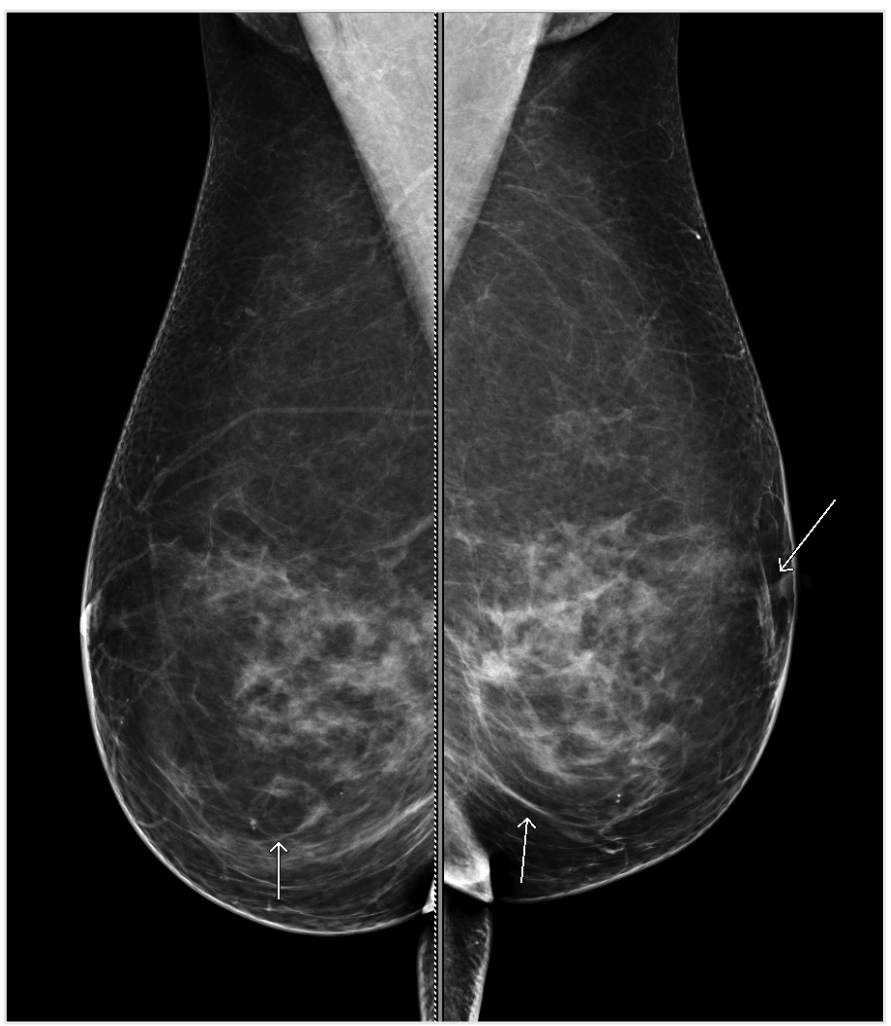

Figure 6. A 49-year-old patient bilateral mammograms postoperative $3^{\text {rd }}$ year following breast reduction shows right breast lower quadrant radiolucent fat cysts with thin wall (left). Left breast image show nipple elevation and lower quadrant fibrotic tractions (right)

\section{Table 5. Summary of radiological findings}

\begin{tabular}{|l|l|l|}
\hline & Frequency & Percentage \\
\hline Parenchymal distortion & 11 & $52.3 \%$ \\
\hline Calcification & 8 & $38.0 \%$ \\
\hline Fat cyst & 7 & $33.3 \%$ \\
\hline Focal fibrosis & 6 & $28.5 \%$ \\
\hline Fat necrosis & 5 & $23.8 \%$ \\
\hline Nipple retraction & 5 & $23.8 \%$ \\
\hline Malignant like peripheral contrast & 3 & $14.2 \%$ \\
\hline Nodular lesion & 1 & $4.7 \%$ \\
\hline Malignant like distortion & 1 & $4.7 \%$ \\
\hline Fluid collection with skin thickening & 1 & $4.7 \%$ \\
\hline
\end{tabular}

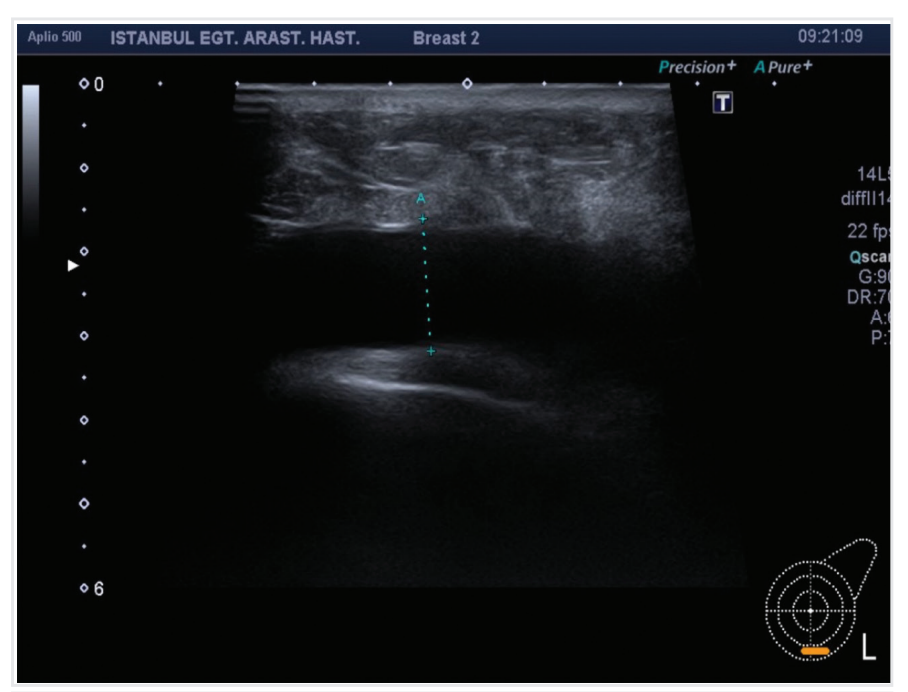

Figure 8. A 53-year-old patient one year after surgery with ultrasonography

image showing an anechoic seroma formation in the lower quadrant

Figure 7. A 39-year-old patient three years following reduction mammoplasty. T1 weighted image (upper left), short inversion time inversion-recovery (upper right), and dynamic contrasted magnetic resonance images show inflamed fat necrosis with high-contrast uptake in the left outer quadrant. Axillary reactive lymph nodes are visible in the left axilla. Ultrasonography images (lower left, lower right) show heterogenic and hyperechogenic images of fat necrosis with hypervascularity in the doppler images 
This enhancement pattern is also observed in malignant tumors, especially in the presence of necrosis. In fat necrosis, suppression of central areas in T1WI in hyperinstense and fat saturated series is typical and important in differential diagnosis (Figure 7) (11-17).

\section{Discussion}

Parenchymal tissue changes such as fat necrosis, fibrosis, scaring, which occur in imaging after a mammaplasty can mimic malignancies. If mammography or ultrasonography is not sufficient to differentiate these lesions from malignancy, MRI or histopathological verification with the biopsy is critical (2). The accurate recognition of the radiologic findings related to surgery in the postoperative period after a mammaplasty is key in distinguishing benign and malignant lesions.

The most common radiological findings in this period include asymmetric reposition of the remaining parenchyma tissue, nipple elevation, common parenchymal calcifications, fat necrosis and cysts, retroareolar fibrotic bands, thickening of the skin and postoperative local fluid collections. In these patients, fat necrosis is the finding with the most similar properties as malignant tumors. Kim et al. (11) revealed that the most frequent mammographic finding of the reduction mammoplasty was nipple elevation (84.3\%). Other findings included retraction of the lower breast (80\%), thickening of the skin (78.6\%), downward shifting of the glandular tissue (47.1\%), retro-areolar fibrotic band (42.9\%), and areolar skin calcification or lipid cyst (35.7\%) (11)

Fat necrosis is often iatrogenic. It is seen in breasts that have undergone surgery and radiotherapy. The most common locations are subareoalar and periareolar regions, but they can also develop in other areas. In our patients, we found that fat necrosis was most commonly located in close proximity to the pedicle. This is due to limited vascularization in this area. Irregularly bounded lesions caused by fat necrosis can mimic breast cancer by causing thickening, withdrawal and parenchymal distortion on the skin. This is an issue especially in patients undergoing surgery or radiotherapy $(18,19)$. Signs of fat necrosis in ultrasonography; solid, semisolid, oval, lobular mass with irregular edges or subcutaneous irregular hyperechoic lesions can be seen. Parenchymal distortion due to fibrotic, inflammatory, and calcified lesions can also be observed. Apart from that, it could be in the form of an anechoic mass with a simple cyst or posterior acoustic shading (18-21).

Long-term MRI findings due to fat necrosis can be fat cysts that hold round contrast. Fat necrosis can also be seen as heterogeneous hyperintense lesions in T1A views, and as heterogeneous hypointense lesion and an irregular or round mass after intravenous gadolinium injection in T2A views $(2,22)$. Isointense parenchymal contrast pattern can be seen as a peripheral ring or nodule. In kinetic studies, the pattern of contrast specific to fat necrosis is unclear (22).

Another finding that can mimic malignancy is focal fibrosis from the proliferation of fibrous connective tissue surrounding ducts and acinus. Radiologically, we observe parenchymal distortion, irregularly-bounded oval and spicule-shaped lesions can be seen. Since these findings are similar to malignancy, it is necessary to perform biopsy for definitive diagnosis if there is no history of surgery, trauma, radiotherapy $(19,21,23)$.
To avoid biopsy, it is necessary to properly define the spectrum of fat necrosis. There are no comprehensive studies to classify the postoperative changes of patients who have undergone a reduction mammaplasty. The role of ultrasonographic evaluation is evolving with technical developments. With high resolution ultrasonography, malignancies can often be discriminated (2). MRI is not a routine diagnostic method in the diagnosis of breast lesions but can be used in the presence of lesions that cannot be diagnosed by other radiological methods (19). Fat necrosis can still be difficult to diagnose, and in some cases, diagnosis is done with a tru-cut biopsy.

\section{Study Limitations}

This study has several limitations. First, it was a retrospective study and the patients were recruited from a single-center. Standardization of participants was not optimal and future prospective randomized studies could overcome these limitations.

\section{Conclusion}

Physicians need to adequately inform patients about the need for future ultrasound and biopsy after surgery. Moreover, the characteristics of palpable nodules and radiological findings after a mammaplasty require exploration in order to differentiate other lesions from malignant ones. Furthermore, patient check-up should be carried out systematically with a team consisting of a radiologist, plastic surgeon, and an oncologist, and they should be advised to continue their routine breast cancer screening.

Ethics Committee Approval: The study approval was obtained by University of Health Sciences Turkey, İstanbul Training and Research Hospital Ethical Committee (approval number: 2660, date: 08.01.2021).

Informed Consent: Informed consents were equally received from all the patients.

Peer-review: Internally peer-reviewed.

Authorship Contributions: Surgical and Medical Practices - G.T., D.A., M.S.; Concept - G.T., D.A., M.A.N., M.S.; Design - G.T., D.A., M.A.N., M.S.; Data Collection or Processing - G.T., D.A., M.S.; Analysis or Interpretation - D.A., M.A.N.; Literature Search - D.A., M.A.N.; Writing - G.T., M.S.

Conflict of Interest: No conflict of interest was declared by the authors.

Financial Disclosure: The authors declared that this study received no financial support.

\section{References}

1. Blaine CM, Subbio CR, Eid SM, Murphy RX Jr. Reduction mammaplasty trends: a quality and fiscal analysis update. Ann Plast Surg 2012; 69: 344-6.

2. Rahbar G, Sie AC, Hansen GC, Prince JS, Melany ML, Reynolds HE, et al. Benign versus malignant solid breast masses: US differentiation. Radiology 1999; 213: 889-94.

3. Quinn EM, Coveney AP, Redmond HP. Use of magnetic resonance imaging in detection of breast cancer recurrence: a systematic review. Ann Surg Oncol 2012; 19: 3035-41.

4. Vasei N, Shishegar A, Ghalkhani F, Darvishi M. Correction to: Fat necrosis in the breast: a systematic review of clinical. Lipids Health Dis 2019; 18: 158. 
5. Hassan HHM, El Abd AM, Abdel Bary A, Naguib NNN. Fat necrosis of the breast: magnetic resonance imaging characteristics and pathologic correlation. Acad Radiol 2018; 25: 985-92.

6. Tan PH, Lai LM, Carrington EV, Opaluwa AS, Ravikumar KH, Chetty N, et al. Fat necrosis of the breast-a review. Breast. 2006; 15: 313-8.

7. Snell L, McCarthy C, Klassen A, Cano S, Rubin L, Hurley K, et al. Clarifying the expectations of patients undergoing implant breast reconstruction: a qualitative study. Plast Reconstr Surg 2010; 126: 1825-30.

8. Piper ML, Esserman LJ, Sbitany H, Peled AW. Outcomes Following Oncoplastic Reduction Mammoplasty: A Systematic Review. Ann Plast Surg 2016; 76(Suppl3): S222-6.

9. Demirdover C, Geyik A, Vayvada H, Menderes A. Is histological evaluation of reduction mammaplasty specimens worthwhile? Aesthet Surg J 2019; 39: NP178-84.

10. Elfituri O, Sonawane $\mathrm{S}, \mathrm{Xu} \mathrm{H}$, Warso MA, Wiley E. A Recurrence of Bilateral Diffuse Sclerosing Lobular Hyperplasia of Breast: A Case Report. Int I Surg Pathol 2018; 26: 353-5.

11. Kim H, Kang BJ, Kim SH, Kim HS, Cha ES. What we should know in mammography after reduction mammoplasty and mastopexy? Breast Cancer 2015; 22: 391-8.

12. Abboud M, Vadoud-Seyedi J, De Mey A, Cukierfajn M, Lejour M. Incidence of calcifications in the breast after surgical reduction and liposuction. Plast Reconstr Surg 1995; 96: 620-6.

13. Bae MS, Han W, Koo HR, Cho N, Chang JM, Yi A, et al. Characteristics of breast cancers detected by ultrasound screening in women with negative mammograms. Cancer Sci 2011; 102: 1862-7.

14. Lee JH, Kim EK, Oh JY, Kwon HC, Kim SH, Kim DC, et al. US screening for detection of nonpalpable locoregional recurrence after mastectomy. Eur J Radiol 2013; 82: 485-9.
15. Miller CL, Feig SA, Fox JW 4th. Mammographic changes after reduction mammoplasty. AJR Am J Roentgenol 1987; 149: 35-8.

16. Robertson JL. Changed appearance of mammograms following breast reduction. Plast Reconstr Surg 1977; 59: 347-51.

17. Tayyab SJ, Adrada BE, Rauch GM, Yang WT. A pictorial review: multimodality imaging of benign and suspicious features of fat necrosis in the breast. $\mathrm{Br}$ J Radiol 2018; 91: 20180213.

18. Sumkin JH, Berg WA, Carter GJ, Bandos Al, Chough DM, Ganott MA, et al. Diagnostic performance of mri, molecular breast imaging, and contrastenhanced mammography in women with newly diagnosed breast cancer Radiology 2019; 293: 531-40.

19. Wang J, Liu Y, Zhang GL, Peng F, Wang Z, Li JH. Breast Rosen triad: a clinicopathologic analysis of 5 cases. Zhonghua Bing Li Xue Za Zhi 2017; 46: 49-50.

20. Berg WA, Bandos Al, Mendelson EB, Lehrer D, Jong RA, Pisano ED. Ultrasound as the primary screening test for breast cancer: analysis from ACRIN 6666. J Natl Cancer Inst 2016; 108: djv367.

21. Shin HJ, Chae EY, Choi WJ, Ha SM, Park JY, Shin KC, et al. Diagnostic performance of fused diffusion-weighted imaging using unenhanced or postcontrast T1weighted MR imaging in patients with breast cancer. Medicine (Baltimore) 2016; 95: e3502.

22. Solomon B, Orel S, Reynolds C, Schnall M. Delayed development of enhancement in fat necrosis after breast conservation therapy: a potential pitfall of MR imaging of the breast. AJR Am J Roentgenol 1998; 170: 966-8.

23. Venta LA, Wiley EL, Gabriel H, Adler YT. Imaging features of focal breast fibrosis: mammographic-pathologic correlation of noncalcified breast lesions. AJR Am J Roentgenol 1999; 173: 309-16. 